\title{
РОДИНА SALICACEAE МІRВ. У ПРИРОДНІЙ ФЛОРІ УКРАЇНИ: ТАКСОНОМІЯ, ХОРОЛОГІЯ, ОХОРОНА
}

\author{
Іщук Л. П., Іщук Г. П.
}

\section{ВСТУП}

Глобальні кліматичні зміни та порівняно зростаючий в Україні антропогенний вплив на природні та штучні лісові насадження створюють проблеми збереження, збагачення та відновлення як видового, так і внутрішньовидового їх різноманіття. Лісові екосистеми виконують важливу еколого-стабілізуючу функцію та мають значну господарську цінність і належать до національного багатства держави. У цьому плані важливу роль відіграють поліморфні види зі значним географічним ареалом i широкою екологічною амплітудою умов зростання. Особливо це актуально для рослин родини Salicaceae Mirb., яка в Україні охоплює два чисельні поліморфні роди бореальної й арктичної флори Populus L. i Salix L. та $є$ однією з найбільших у бореальній арборифлорі, налічуючи, за різними даними, $300-550^{1}(700)^{2}$ видів. Переважна більшість вербових поширена в Голарктичному царстві, де родина Salicaceae є ендемічною.

Поліморфність життєвих форм і широка екологічна пластичність видів родів Populus і Salix створює передумови для вивчення міжвидової та внутрішньовидової мінливості залежно від грунтово-кліматичних умов та екстремальних факторів екотопів, що можуть бути осередками формоутворення, своєрідними мікроеволюційними полігонами. Поліваріантність онтогенезу виду та його насаджень різного генезису, структури і вік, робить природні популяції та насадження різного функціонального призначення масштабною природною лабораторією для дослідження фундаментальних проблем екології та системного визначення діагнозу їх стійкості й адаптаційних можливостей. Характерною особливістю видів родина Salicaceae є швидкі темпи росту і накопичення значної біомаси за короткий період часу. Однак нині не достатньо відомостей про те, наскільки уже створені фітоценози спроможні до сталого розвитку за умов глобальних змін клімату, зокрема посилення його аридних рис. Кліматичні зміни та часто невелика площа насаджень призводить до скорочення та збіднення їх

\footnotetext{
${ }^{1}$ Горєлов О.M. Родина Salicaceae Mirb. Дендрофлора України: Дикорослі й культивовані дерева і кущі. Покритонасінні / за ред. М.А. Кохна. Київ : Фітосоціоцентр, 2002. Ч. 1. С. 336-379.

${ }^{2}$ The Angiosperm Phylogeny Group. An update of the Angiosperm Phylogeny Group classification for the orders and families of flowering plants: APG IV. Botanical Journal of the Linnean Society. 2016. Vol. 181. № 1 (24 March). P. 1-20. DOI:10.1111/boj.12385.
} 
таксономічного складу, що важливо для розробки прогностичних програм збереження і збагачення та прогнозування наслідків впливу. Тому напрацювання і впровадження питань таксономічного складу, хорології, екології й охорони рослин родини Salicaceae актуальні для ботаніки, дендрології, фітоценології, фітомеліорації, селекції та збагачення фіторізноманіття природних насаджень.

\section{1. Таксономічний аналіз і хорологія видів родини Salicaceae в Україні}

Родина Salicaceae у флорі України за кількістю видів належить до провідних деревних родин і нараховує, за різними даними, 26-33 автохтонні види, які завдяки своїй поліморфності утворюють ряд таксономічних внутрішньовидових відмін. У природній флорі України вона представлена двома родами Populus i Salix ${ }^{34}$. На території України природне різноманіття роду Populus обмежене лише трьома видами й одним дикорослим гібридом, котрі належать до двох секцій (табл. 1).

Таблиця 1

Таксономічні особливості та хорологія видів роду Populus в Україні

\begin{tabular}{|c|c|c|c|}
\hline Секція & Вид & $\begin{array}{l}\text { Життєва } \\
\text { форма }\end{array}$ & Поширення в Україні \\
\hline \multirow[t]{3}{*}{ Leuce } & $\begin{array}{l}P . \text { alba L. - тополя } \\
\text { біла }\end{array}$ & Фанерофіт & $\begin{array}{l}\text { По всій території України за } \\
\text { винятком крайнього півдня, але } \\
\text { характерна для Криму. } \\
\text { У Карпатах росте в передгір'ях, } \\
\text { рідше в горах. }\end{array}$ \\
\hline & $\begin{array}{l}\text { P. tremula L. - тополя } \\
\text { тремтяча або осика }\end{array}$ & Фанерофіт & $\begin{array}{l}\text { По всій території України й у } \\
\text { Криму, за винятком південного } \\
\text { сходу. }\end{array}$ \\
\hline & $\begin{array}{l}P . \times \text { canescens (Ait.) } \\
\text { Smith.) - тополя } \\
\text { сірувата (природний } \\
\text { гібрид (P. hybrida } \\
\text { Bieb. = P. alba } \times \\
P . \text { tremula Aschers. }\end{array}$ & Фанерофіт & $\begin{array}{l}\text { У місцезростаннях батьківських } \\
\text { форм, головним чином на } \\
\text { Поліссі. }\end{array}$ \\
\hline Aegeiros & $\begin{array}{l}\text { P. nigra L. - тополя } \\
\text { чорна }\end{array}$ & Фанерофіт & $\begin{array}{l}\text { По всій території України, за } \\
\text { винятком Карпат, Прикарпаття і } \\
\text { південного сходу }\end{array}$ \\
\hline
\end{tabular}

Найбільше різноманіття роду Populus у природній флорі представлено видами із секції Білі тополі (Leuce), до яких належать три види - P. alba,

\footnotetext{
${ }^{3}$ Назаров М.I., Котов M.I., Гержедович П.І. Вербові (Salicaceae Lindl.). Флора УРСР. Київ : Вид-во AH УРCP, 1952 T. IV. C. $17-86$.

${ }^{4}$ Чопик В., Федорончук М. Флора Українських Карпат. Тернопіль : ТзОВ «Терно-граф», 2015. $712 \mathrm{c}$. 
P. tremula i P. $\times$ canescens. Секція чорні тополі (Aegeiros) у природній флорі представлена одним видом - тополя чорна, або осокір (P. nigra L.).

Зазвичай $P$. alba створює заплавні галерейні ліси та гаї в долинах річок, западинах між пісками, на заплавах поліських річок та інших приток Дніпра й утворює угрупування топольники, що є початковою стадією перетворення топольників на діброви. Ацидофільний вид P. tremula приурочена до вододільних і долинних лісів, схилів, боліт і плавнів, трапляється по окраїнах саг, у западинах між піщаними кучугурами і зрідка на сухих пісках. В Україні $P$. nigra поширений у долинах річок, у плавнях і сагах по всій території. Осокорові ліси у заплаві Дніпра на Поліссі відсутні. У долині середньої та нижньої течії Дніпра P. nigra є едифікатором і субедифікатором, також поширений у заплавах річок Самара, Оріль, Вовча, Ворскла.

Представники роду Salix L. в Україні зазвичай займають інтразональні ландшафти перезволожених екотопів. На думку О.К. Скворцова ${ }^{5}$, складність в ідентифікації видів роду Salix полягає в тому, що вони дуже поліморфні, мають велику кількість міжвидових спонтанних гібридів, характеризуються неодночасним розвитком листків i квіток та дводомністю. Тому питання їх кількості досі дискусійне. Впродовж останнього століття флору роду Salix в Україні аналізували M.I. Назаров та ін. ${ }^{6}$, котрі опублікували академічне видання «Флора УРСР», де рід Salix представлений 30 видами, поширеними переважно у Карпатах, Поліссі та Лісостепу України. Із них три види поширені тільки в культурі S. babylonica L. - на півдні, S. elegantissima Koch. - у західних областях України та в Польщі та $S$. dasyclados - у західних областях України. Востаннє флору роду Salix України детально аналізував. О.К. Скворцов ${ }^{7}$, укладаючи академічне видання «Определитель высших растений Украины». Флору роду Salix в Українських Карпатах аналізував В.В. Крічфалушій ${ }^{8}$, а хорологію чагарникових і болотних видів роду Salix України - Т.Л. Андрієнко ${ }^{9}$, Д.М. Голяка та ін. ${ }^{10}$ Види роду Salix також вивчали румунські, угорські, чеські, словацькі австрійські та польські вчені, дослідження яких відображені у фітоценотичних і фітогеографічних працях, присвячених флорі Карпат,

\footnotetext{
${ }^{5}$ Skvortsov A.K. Willows of Russia and Adjacent Countries. Taxonomical and Geographical Revision. Joensuu : University of Joensuu, 1999. 307 p.

${ }^{6}$ Назаров M.I., Котов М.І., Гержедович П.І. Вербові (Salicaceae Lindl.). Флора УРСР. Київ : Вид-во АН УРСР, 1952 T. IV. C. 17-86.

7 Скворцов A.K. Salix L. Определитель высиих растений Украины. Київ : Наук. думка, 1987. C. $130-133$.

${ }^{8}$ Крічфалушій В.В. Види роду Salix L. в Українських Карпатах. Укр. ботан. журн. 1982. 39, № 2. С. 52-56.

9 Андриенко Т.Л. Мелкие болотные ивы (Salix lapponum, S. myrtilloides, S. rosmarinifolia). Ботанический журнал. 1980. Т. 65. № 6. С. 843-848.

${ }^{10}$ Голяка Д.М., Білоус А.М., Голяка М.А. Фітомаси чагарникових верб у природних фітоценозах Чернігівського Полісся : монографія. Київ : НУБіП України, 2018. 227 с.
} 
зокрема Г. Запалович ${ }^{11}$, Е. Волощак ${ }^{12}$, В. Шафер ${ }^{13}$, К. Домін $^{14}$. За даними B.B. Крічфалушія ${ }^{15}$ S. alpina Scop., S. hastata L., S. herbaceae L., S. kitaibeliana Willd., S. lapponum L., S. phylicifolia L., S. retusa L. рідкісні арктоальпійські й альпійські види - релікти льодовикової доби. Ці види характеризуються постійністю ценозів. Виходячи зі схеми висотної поясності, автор розподілив флору роду Salix Українських Карпат на чотири флороценотичні комплекси: альпійські, субальпійські, монтанно-субальпійські та придаткові види. У «Флорі УРСР» ${ }^{16}$ для Карпат наведено 23 автохтонні види роду Salix, у «Визначнику рослин України» Є.М. Брадіс ${ }^{17}-24$ види. Дискусія щодо кількості видів роду Salix актуальна і тепер. Дослідники впродовж останнього століття одні й ті самі види відносили у ранг синонімів або підвидів (табл. 2).

В останній фундаментальній роботі В.I. Чопик, М.М. Федорончук ${ }^{18}$ «Флора Українських Карпат» для флори роду Salix наводять 25 видів, із них два S. babylonica L. i S. × blanda Anders. трапляються тільки в культурі. Також автори висловлюють сумніви щодо наявності у флорі Карпат S. hastata L. i S. reticulata, оскільки останній вид не підтверджується гербарними зразками.

Таким чином, як видно із проведеного аналізу, кількість аборигенних видів роду Salix і нині залишається дискусійною та за різними даними нараховує 22-27 видів. Більшість дослідників сходяться на цифрі 24-25 видів, хоча висловлюють сумніви щодо наявності S. hastata L. і S. reticulata в Україні. Внаслідок проведених нами експедиційних досліджень у природну флору для обстеження видів роду Salix та аналізу їх гербарних зразків у гербаріях України (KW, LW, LWS, UU, PWU, TERN*, CWU, YALT) нами виділено у природній флорі України 23 види ${ }^{19,20}$ (табл. 3).

\footnotetext{
${ }^{11}$ Zapałowicz H. Conspectus florae Galiciae criticus. Krytyczny Przegląd Roślinności Galicji. Kraków : Akademia Umiejętności, 1908. Vol. 2. 368 p.

${ }^{12}$ Woloszczak E. Kritische Bemerkungen uber sieben burgische Weiden. Osterreich. bot. Z. 1889. № 39. P. 291-295, 330-332.

${ }^{13}$ Szafer W. Salicaceae. Flora Polska. 1921. № 2. S. 24-47. Krakow

${ }^{14}$ Domin K. Additarnenta ad cognitionem florae Rossiae Subcarpaticae. Acta bot. Bohem. Praha. 1929. № 8 (37). P. 35-44.

${ }^{15}$ Крічфалушій В.В. Види роду Salix L. в Українських Карпатах. Укр. ботан. журн. 1982. 39, № 2. C. $52-56$.

${ }^{16}$ Назаров M.I., Котов M.І., Гержедович П.І. Вербові (Salicaceae Lindl.). Флора УРСР. Київ : Вид-во АН УРСР, 1952 Т. IV. С. 17-86.

${ }^{17}$ Брадіс C.M. Salix L. Визначник рослин Украӥни / за ред. Д.К. Зерова. Київ : Урожай, 1965. C. $186-193$.

18 Чопик В., Федорончук М. Флора Українських Карпат. Тернопіль : ТзОВ «Терно-граф», $2015.712 \mathrm{c}$.

${ }^{19}$ Іщук Л.П. Рід Salix L. в Україні. Bicmi біосферного заповідника «Асканія-Нова». 2015. Вип. 17. C. $97-100$.

${ }^{20}$. Іщук Л.П. Родина Salicaceae Mirbel.: біологія, адаптаційний потенціал, охорона та використання в Україні : дис. ... докт. біол. наук : 03.00.05. Київ, 2019. 585 с. 


\section{Трактування деяких таксономічних одиниць роду Salix у межах території України}

\begin{tabular}{|c|c|c|c|}
\hline \multirow[b]{2}{*}{ Назва таксону } & \multicolumn{3}{|c|}{ Трактування таксону за різними авторами } \\
\hline & О.К. Скворцов ${ }^{21}$ & $\begin{array}{c}\text { M.I. Назаров та ін. } \\
\text { Є.М. Брадіс } \\
\text { В. } \\
\text { В.В. Крічфалушій }\end{array}$ & $\begin{array}{c}\text { В.І. Чопик, } \\
\text { М.М. Федорончук }\end{array}$ \\
\hline S. xerophila & $\begin{array}{l}\text { Синонім } S . \\
\text { bebbiana Sarg. }\end{array}$ & $\begin{array}{l}\text { Заміщена S. Starkeana } \\
\text { Willd. синонім S. livida } \\
\text { Wahl. }\end{array}$ & - \\
\hline $\begin{array}{l}\text { S. Kitaibelliana } \\
\text { Willd. }\end{array}$ & $\begin{array}{l}\text { Різновид } S . \text { retusa } \\
\text { L. }\end{array}$ & S. Kitaibelliana Willd. & Синонім $S$. retusa L. \\
\hline S. repens L. & $\begin{array}{l}\text { Заміщена } S . \\
\text { rosmarinifolia L. }\end{array}$ & S. repens L. & - \\
\hline S. Jaquinii Host. & $\begin{array}{l}\text { Синонім S. alpina } \\
\text { Scop. }\end{array}$ & S. Jaquinii Host. & - \\
\hline S. nigricans Sm. & $\begin{array}{l}\text { Синонім } S . \\
\text { myrsinifolia } \text { Salisb. }\end{array}$ & S. nigricans $\mathrm{Sm}$. & $\begin{array}{l}\text { Синонім } \\
\text { S. myrsinifolia Salisb. }\end{array}$ \\
\hline $\begin{array}{l}\text { S. incana } \\
\text { Schrank. }\end{array}$ & $\begin{array}{l}\text { Синонім } S . \\
\text { eleagnos Scop. }\end{array}$ & S. incana Schrank. & Синонім $S$. elaeagnos \\
\hline S. phylicifolia L. & - & - & $\begin{array}{l}\text { Синонім S. rhaetica } \\
\text { Anders. }\end{array}$ \\
\hline S. elegans Bess. & - & - & $\begin{array}{l}\text { Синонім } \\
\text { S. myrtilloides L. }\end{array}$ \\
\hline
\end{tabular}

Таблиця 3

\section{Таксономічні особливості та хорологія представників роду Salix в Україні}

\begin{tabular}{|c|c|c|c|c|}
\hline Підрід & Секція & $\begin{array}{c}\text { Вид, підвид, деякі } \\
\text { синоніми }\end{array}$ & Життєві форми & Поширення в Україні \\
\hline 1 & 2 & 3 & 4 & 5 \\
\hline \multirow{3}{*}{ 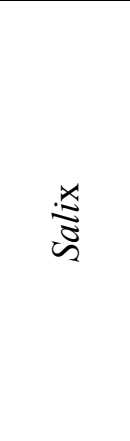 } & Amygdalinae & $\begin{array}{l}\text { S. triandra L. - } \\
\text { верба } \\
\text { тритичинкова }\end{array}$ & Мікрофанерофіт & $\begin{array}{l}\text { Полісся, Лісостеп, Степ, } \\
\text { Карпати, Крим. }\end{array}$ \\
\hline & Pentandrae & $\begin{array}{l}\text { S. pentandra L. - } \\
\text { верба } \\
\text { п'ятитичинкова }\end{array}$ & $\begin{array}{l}\text { Мікро-, рідше } \\
\text { мезофанерофіт }\end{array}$ & $\begin{array}{l}\text { Полісся, зрідка в } \\
\text { Лівобережному, } \\
\text { Правобережному, } \\
\text { Волинському і Західному } \\
\text { Лісостепу. }\end{array}$ \\
\hline & Salix & $\begin{array}{l}\text { S. alba L. - верба } \\
\text { біла }\end{array}$ & Мезофанерофіт & $\begin{array}{l}\text { Полісся, Лісостеп, Степ, } \\
\text { Карпати, Крим. }\end{array}$ \\
\hline
\end{tabular}

${ }^{21}$ Скворцов А.К. Ивы СССР. Москва : Наука, 1968. 262 с.

22 Назаров M.І., Котов М.I., Гержедович П.І. Вербові (Salicaceae Lindl.). Флора УРСР. Київ : Вид-во АН УРСР, 1952 Т. IV. С. 17-86.

${ }^{23}$ Брадіс C.M. Salix L. Визначник рослин Украӥни / за ред. Д.К. Зерова. Київ : Урожай, 1965. С. 186-193.

${ }^{24}$ Крічфалушій В.В. Види роду Salix L. в Українських Карпатах. Укр. ботан. журн. 1982. 39 , № 2. C. $52-56$.

25 Чопик В., Федорончук М. Флора Українських Карпат. Тернопіль : ТзОВ «Терно-граф», 2015. 712 c. 
Продовження табл. 3

\begin{tabular}{|c|c|c|c|c|}
\hline 1 & 2 & 3 & 4 & 5 \\
\hline 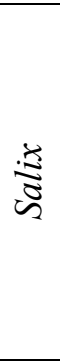 & Salix & $\begin{array}{l}\text { S. fragilis - верба } \\
\text { ламка }\end{array}$ & Мезофанерофіт & $\begin{array}{l}\text { Полісся, Лісостеп, Степ, } \\
\text { Карпати, гірський Крим. } \\
\text { Південна межа проходить по } \\
\text { лінії Таганрог (Росія) - } \\
\text { Пологи - Каховка - } \\
\text { Цюрупинськ - Очаків і далі } \\
\text { на захід по узбережжю } \\
\text { Чорного моря. }\end{array}$ \\
\hline \multirow{4}{*}{ 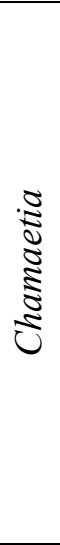 } & Myrtilloides & $\begin{array}{l}\text { S. myrtilloides L. - } \\
\text { верба чорнична }\end{array}$ & $\begin{array}{l}\text { Нанофанерофіт, } \\
\text { рідше хамефіт }\end{array}$ & $\begin{array}{l}\text { Полісся, Лісостеп, Карпати. } \\
\text { Південна межа ареалу } \\
\text { проходить по лінії Семенівка } \\
\text { - Прилуки - Золотоноша - } \\
\text { Київ - Городниця - Костопіль } \\
\text { - Ковель. }\end{array}$ \\
\hline & \multirow[t]{2}{*}{ Retusa } & $\begin{array}{l}\text { S. herbaceae L. - } \\
\text { верба трав’яниста }\end{array}$ & Хамефіт & Карпати \\
\hline & & $\begin{array}{l}\text { S. retusa L.- верба } \\
\text { туполиста }\end{array}$ & Хамефіт & Карпати \\
\hline & Myrtosalix & \begin{tabular}{|l|} 
S. alpina Scop. - \\
верба альпійська
\end{tabular} & Хамефіт & Карпати \\
\hline \multirow{7}{*}{$\frac{5}{2}$} & Nigricantes & $\begin{array}{l}\text { S. myrsinifolia } \\
\text { Salisb. - верба } \\
\text { мірзинолиста } \\
\text { (S. nigricans } \mathrm{Sm} . \text {, } \\
\text { S. borealis } \text { Fr. } \\
\text { Nass.) }\end{array}$ & Мікрофанерофіт & $\begin{array}{l}\text { Полісся. Південна межа } \\
\text { проходить по лінії Чернігів - } \\
\text { Суми і далі по кордону між } \\
\text { Білоруссю і Україною. }\end{array}$ \\
\hline & \multirow[t]{3}{*}{$\begin{array}{l}\text { Vetrix, } \\
\text { підсекція } \\
\text { Laeves }\end{array}$} & $\begin{array}{l}\text { S. caprea } \mathrm{L} .- \\
\text { верба козяча } \\
\text { (S. coaetance } \\
\text { (Hartm.) Flod.; } \\
\text { S. caprea } \\
\text { coaetanea } \text { Hartm.) } \\
\end{array}$ & Мікрофанерофіт & $\begin{array}{l}\text { Полісся, Лісостеп, Степ, } \\
\text { Карпати, Крим. } \\
\text { Південна межа проходить по } \\
\text { лінії Миколаїв - Запоріжжя - } \\
\text { Донецьк. }\end{array}$ \\
\hline & & $\begin{array}{l}\text { S. cinerea } \text { L. - } \\
\text { верба сіра, } \\
\text { попеляста }\end{array}$ & Нанофанерофіт & $\begin{array}{l}\text { Полісся, Лісостеп, Степ, } \\
\text { Карпати, Крим. }\end{array}$ \\
\hline & & $\begin{array}{l}\text { S. aurita L. - верба } \\
\text { вушката }\end{array}$ & Нанофанерофіт & $\begin{array}{l}\text { Полісся, Карпати. Південна } \\
\text { межа проходить по лінії } \\
\text { Суми - Київ, далі включаючи } \\
\text { Західний Лісостеп, } \\
\text { переходить у Карпати. }\end{array}$ \\
\hline & \multirow[t]{2}{*}{\begin{tabular}{|l} 
Vetrix, \\
підсекція \\
Substriatae
\end{tabular}} & $\begin{array}{l}\text { S. starkeana Willd. } \\
\text { - верба Старке } \\
\text { (S. livida } \text { Whlbg., } \\
\text { S depressa } \text { L. p.p.) }\end{array}$ & Нанофанерофіт & $\begin{array}{l}\text { Полісся, Лісостеп, Карпати. } \\
\text { Південна межа проходить по } \\
\text { лінії Харків - Полтава - } \\
\text { Лубни - Канів - Вінниця - } \\
\text { Рогатин - Львів - Мостиськ. }\end{array}$ \\
\hline & & $\begin{array}{l}\text { S. silesiaca Willd. - } \\
\text { верба сілезька }\end{array}$ & Мікрофанерофіт & Карпати \\
\hline & \begin{tabular}{|l|} 
Arbuscella, \\
Підсекція \\
Bicolores \\
\end{tabular} & $\begin{array}{l}\text { S. rhaetica Anders. } \\
\text { - верба ретійська }\end{array}$ & $\begin{array}{l}\text { Нанофанерофіт, } \\
\text { рідше хамефіт }\end{array}$ & Карпати \\
\hline
\end{tabular}


Закінчення табл. 3

\begin{tabular}{|c|c|c|c|c|}
\hline 1 & 2 & 3 & 4 & 5 \\
\hline \multirow{5}{*}{$\frac{5}{2}$} & Vimen & $\begin{array}{l}\text { S. viminalis L. - } \\
\text { верба прутовидна, } \\
\text { кошикова } \\
\text { конопляна } \\
\text { (S. rossica } \text { Nass.) } \\
\end{array}$ & Мікрофанерофіт & $\begin{array}{l}\text { Полісся, Лісостеп, Карпати. } \\
\text { Південна межа проходить по } \\
\text { лінії Харків - Черкаси - } \\
\text { Балта. }\end{array}$ \\
\hline & Villosae & $\begin{array}{l}\text { S. lapponum L. - } \\
\text { лапландська, } \\
\text { лопарська }\end{array}$ & Нанофанерофіт & $\begin{array}{l}\text { Полісся, Лісостеп, Карпати. } \\
\text { Південна межа суцільного } \\
\text { ареалу проходить по лінії } \\
\text { Овруч - Новоград- } \\
\text { Волинський - північніше } \\
\text { Рівного - Луцьк - Ковель, а } \\
\text { південна межа острівного } \\
\text { поширення по лінії Шостка - } \\
\text { Ніжин - Київ - Житомир - } \\
\text { Сокаль. }\end{array}$ \\
\hline & Daphnella & $\begin{array}{l}\text { S. acutifolia Willd. } \\
\text { - верба } \\
\text { гостролиста } \\
\text { (червона шелюга) }\end{array}$ & Мікрофанерофіт & $\begin{array}{l}\text { Лівобережне Полісся, } \\
\text { Лівобережний Лісостеп, } \\
\text { Степ. }\end{array}$ \\
\hline & & $\begin{array}{l}\text { S. daphnoides Vill. } \\
\text { - верба } \\
\text { вовчеягідна }\end{array}$ & $\begin{array}{l}\text { Мікро-, рідше } \\
\text { мезофанерофіт }\end{array}$ & Карпати \\
\hline & Incubaceae & $\begin{array}{l}\text { S. rosmarinifolia L. } \\
\text { - верба } \\
\text { розмаринолиста }\end{array}$ & Нанофанерофіт & $\begin{array}{l}\text { Лівобережний Лісостеп, } \\
\text { Степ, Крим. Південна межа } \\
\text { проходить по лінії через } \\
\text { Броди - Кременець - } \\
\text { Житомир - Золотоношу - } \\
\text { Сосницю - Новгород- } \\
\text { Сіверський. }\end{array}$ \\
\hline \multirow{3}{*}{ 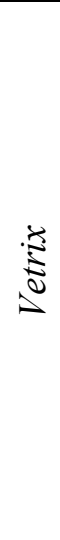 } & Cannae & $\begin{array}{l}\text { S. elaeagnos Scop. } \\
\text { - верба } \\
\text { маслинколиста, } \\
\text { лоховидна }\end{array}$ & Мікрофанерофіт & Карпати. \\
\hline & \multirow[t]{2}{*}{\begin{tabular}{|l|} 
Helix \\
підсекція \\
Purрureae
\end{tabular}} & \begin{tabular}{|l} 
S. purpurea L. - \\
верба пурпурова
\end{tabular} & Нанофанерофіт & $\begin{array}{l}\text { Полісся, Лісостеп, гірський } \\
\text { Крим. Південна межа } \\
\text { проходить по лінії Ковель - } \\
\text { Вінниця - Білгород- } \\
\text { Дністровський. } \\
\end{array}$ \\
\hline & & \begin{tabular}{|l|} 
S. Vinogradovii \\
Skvorts. - верба \\
Виноградова \\
\end{tabular} & Нанофанерофіт & $\begin{array}{l}\text { Лівобережний Лісостеп, } \\
\text { Степ. }\end{array}$ \\
\hline
\end{tabular}

Таким чином, нами чітко встановлено хорологію лише 23 видів роду Salix в Україні. Ще два види, які традиційно описують дослідники, потребують уточнення. Зокрема, для території Українських Карпат S. reticulata із секції Chamaetia однойменного підроду Chamaetia ${ }^{26}$.

\footnotetext{
${ }^{26}$ Ishchuk L.P. Analysis of willow (Salix L.) Flora in Ukrainian Carpathians. Journal of botany. 2017. Vol. IX. № 1 (14). P. 50-55.
} 
У друге видання Червоної книги України ${ }^{27}$ до категорії зникаючих було зараховано $S$. reticulata, місцезростання якої описані лише на масиві Чорногора (хребет Піп Іван, 1977) у Карпатах і на Полонині Руна, однак в останньому виданні Червоної книги України ${ }^{28}$ цей вид відсутній. У визначнику Флори Карпат В.I. Чопик, М.М. Федорончук ${ }^{29}$ зазначають, що вид відомий лише за літературними даними для масиву Чорногори. B.В. Крічфалушій ${ }^{30}$ вважає, що S. reticulata відсутня в Українських Карпатах. Його появу пов'язують із даними В. Шафера ${ }^{31}$, який вказує цей вид для масиву Чорногори. Всі ж наступні автори опираються лише на нього і не підтвердили цей вид гербарними зборами 3 цього району. Дослідники флори Карпат Г. Запалович ${ }^{32}$ та Е. Волощак ${ }^{33}$ S. reticulata для українських Карпат не вказують.

Внаслідок наших маршрутних досліджень і аналізу гербарних зразків S. reticulata не знайдено. У гербаріях Львова (LW), (LWS) представлені гербарні зразки S. reticulata з Польщі, Румунії, Словаччини. Тому, імовірно, цей вид відсутній в Українських Карпатах ${ }^{34,35,36}$.

Ще один вид $S$. hastata наводять дослідники для території Українських Карпат 3 однойменної секцї Hastatae підроду Vetrix. В Україні $S$. hastata вказується для масиву Чорногора ${ }^{37}$. Однак Е. Волощак ${ }^{38}$ відносить описаний Е. Запаловичем ${ }^{39}$ вид до S. phylicifolia= S.rhetica. О.К. Скворцов ${ }^{40}$ також вважає його помилковим для Український Карпат. У наступній праці Е. Запалович ${ }^{41}$ цей вид для

27 Червона книга України. Рослинний світ. Київ : Українська енциклопедія, 1996. 486 с.

${ }^{28}$ Червона книга України. Рослинний світ / за ред. Я.П. Дідуха. Київ : Глобалконсалтинг, 2009. 900 с.

${ }^{29}$ Чопик В., Федорончук М. Флора Українських Карпат. Тернопіль : ТзОВ «Терно-граф», 2015. 712 с.

${ }^{30}$ Крічфалушій В.В. Види роду Salix L. в Українських Карпатах. Укр. ботан. журн. 1982. 39, № 2. C. $52-56$.

${ }^{31}$ Szafer W. Salicaceae. Flora Polska. 1921. № 2. S. 24-47. Krakow.

32 Zapałowicz H. Conspectus florae Galiciae criticus. Krytyczny Przegląd Roślinności Galicji. Kraków: Akademia Umiejętności, 1908. Vol. 2. 368 p.

${ }^{33}$ Woloszczak E. Kritische Bemerkungen uber sieben burgische Weiden. Osterreich. bot. Z., 1889. № 39. P. 291-295, 330-332.

${ }^{34}$ Іщук Л.П. До хорології та охорони видів роду Salix L. Флорологія та фітосозологія. 2014. T. 3-4. C. $38-42$.

${ }^{35}$ Іщук Л.П. Таксономічний склад та деякі аспекти використання автохтонних видів роду Salix L. в Українських Карпатах. Основні проблеми й тенденції подальшого розвитку лісового господарства 8 Українських Kaрnaтах : зб. матеріалів Міжнародної науково-практичної конференції (4-5 жовтня 2018 р., м. Івано-Франківськ). Івано-Франківськ : НАІР, 2018. С. 210-215

${ }^{36}$ Ishchuk L.P. Analysis of willow (Salix L.) Flora in Ukrainian Carpathians. Journal of botany. 2017. Vol. IX. № 1 (14). P. 50-55.

${ }^{37}$ Zapałowicz H. Roślinna szata gớr Pokucko-Marmaroskich. Sprav. Kom. Fizjogr. Umiej, 1889. 389 p.

${ }^{38}$ Woloszczak E. Kritische Bemerkungen uber sieben burgische Weiden. Osterreich. bot. Z. 1889. № 39. P. 291-295, 330-332.

${ }^{39}$ Zapałowicz H. Roślinna szata gớr Pokucko-Marmaroskich. Sprav. Kom. Fizjogr. Umiej, 1889. 389 p.

${ }^{40}$ Skvortsov A.K. Willows of Russia and Adjacent Countries. Taxonomical and Geographical Revision. Joensuu : University of Joensuu, 1999. 307 p.

${ }^{41}$ Zapałowicz H. Conspectus florae Galiciae criticus. Krytyczny Przegląd Roślinności Galicji. Kraków : Akademia Umiejętności, 1908. Vol. 2. 368 p. 
Карпат вже не вказує. Пізніше К.А. Малиновський ${ }^{42}$ знову наводить цей вид для Карпат на г. Петрос. На думку В.В. Крічфалушія ${ }^{43}, S$. hastata потребує цілковитої охорони всіх місцезростань. Віддає перевагу вапняковим субстратам. У визначнику Флори Карпат B.I. Чопик, М.М. Федорончук ${ }^{44}$ також вважають, що вид для Українських Карпат, імовірно, наводиться помилково.

У гербаріях Львова (LW, LWS) ми оглянули гербарні зразки S. Hastata, зібрані А. Кернером, А. Реманом із Польщі та Словаччини. У гербарії Національного природознавчого музею (LWS) представлені гербарні зразки S. hastata К. Малиновського, зібрані 1955 р., і Л. Тасєнкевич, зібрані у 1977-1978 рр. із хребта Чорногора. В останньому виданні Червоної книги України ${ }^{45}$ S. hastata не згадується. Тому місцезростання цього виду потребують уточнення.

Майже всі аборигенні види роду Salix - гігрофіти і геліофіти, тому дуже швидко заселяють нові місця та техногенні ландшафти. Крім того, у природі часто трапляються спонтанні гібриди. Слід зауважити, що вони не мають домінуючого значення у популяціях. О.К. Скворцов ${ }^{46}$, аналізуючи історію вивчення видів роду Salix, виділяв період масового опису та виявлення гібридів, але він вважав, що гібридизація має обмежений характер і зазвичай відсутня у видів однієї секції. Однак всетаки він визнавав масову гібридизацію $S$. alba $\times$ S. fragilis, $S$. starkeana $\times$ S. bebbiana, S. repens $\times$ S. rosmarinifolia. H.В. Старова ${ }^{47}$ стверджує, що багато сортів не завжди проявляють відмінні морфологічні ознаки. Рівень гібридизації підвищується на порушених місцезростаннях і на кордонах ареалів видів. Інтрогресивна гібридизація в Україні найчастіше відбувається на Поліссі, у Лісостепу та Карпатах, де представлена найбільша різноманітність видів. У табл. 4 наведено розподіл за географічним принципом I.P. Морозова ${ }^{48}$ ареалів видів роду Salix, поширених в Україні. Внаслідок польових спостережень нами також проаналізовано видові таксони роду Salix у ботаніко-географічних зонах України, і на основі класифікації за географічним принципом виділені масові та поодинокі види, визначені ландшафтні групи.

Види роду Salix поширені у всіх ботаніко-географічних зонах України: Поліссі, Лісостепу, Степу, Карпатах, гірському Криму і на

\footnotetext{
${ }^{42}$ Малиновський К. Рослинність високогір'я Українських Карпат. Київ : Наук. думка, 1980. 276 с.

${ }^{43}$ Крічфалушій В.В. Види роду Salix L. в Українських Карпатах. Укр. ботан. журн. 1982. 39, № 2. C. $52-56$.

${ }_{44}^{44}$ Чопик В., Федорончук М. Флора Українських Карпат. Тернопіль : ТзОВ «Терно-граф», 2015. $712 \mathrm{c}$.

${ }_{45}$ Червона книга України. Рослинний світ / за ред. Я.П. Дідуха. Київ : Глобалконсалтинг, 2009. $900 \mathrm{c}$.

${ }^{46}$ Скворцов А.К. Ивы СССР. Москва : Наука, 1968. 262 с.

${ }^{47}$ Старова Н.В. Селекция ивовых. Москва : Лесн. пром-сть, 1980. 208 с.

${ }^{48}$ Морозов И.Р. Определитель ив и их культура. Москва : Лесная промышленность, 1966. 254 с.
} 
Південному узбережжі Криму. У всіх природних зонах України, за винятком інтразональних типів рослинності, поширені $S$. acutifolia, S. fragilis, S. alba, S. caprea, S. pentandra, S. triandra, S. cinerea, S. viminalis, S. rosmarinifolia ${ }^{49}$.

Таблиця 4

\section{Географічні групи ареалів Salix L., характерні для України}

\begin{tabular}{|l|l|}
\hline \multicolumn{1}{|c|}{ Географічна група ареалів } & \multicolumn{1}{|c|}{ Види, поширені в Україні } \\
\hline $\begin{array}{l}\text { I. Багатозональні види (ареали поширення } \\
\text { на більшій частині материка Євразія) }\end{array}$ & $\begin{array}{l}\text { S. caprea, S. pentandra, S. alba, } \\
\text { S. triandra, S. Starkeana, S. cinerea }\end{array}$ \\
\hline $\begin{array}{l}\text { II. Свропейські види (ареали в межах } \\
\text { Європи) }\end{array}$ & $\begin{array}{l}\text { S. fragilis, S. aurita, S. viminalis, } \\
\text { S. purpurea, S. daphnoides, } \\
\text { S. elaeagnos }\end{array}$ \\
\hline $\begin{array}{l}\text { III. Східно-європейські види (ареали в } \\
\text { межах Східної Свропи) }\end{array}$ & S. acutifolia, S. silesiaca \\
\hline $\begin{array}{l}\text { IV. Свросибірські види (ареали в межах } \\
\text { Північної та Середньої Європи та Сибіру) }\end{array}$ & $\begin{array}{l}\text { S. rhaetica, S. lapponum, } \\
\text { S. myrtilloides, S. myrsinifolia, } \\
\text { S. rosmarinifolia, S. Vinogradovii }\end{array}$ \\
\hline $\begin{array}{l}\text { V. Аркто-альпійські види (ареали } \\
\text { охоплюють арктичну й альпійську тундри) }\end{array}$ & S. herbacea, S. retusa, S. alpina. \\
\hline
\end{tabular}

Вузькозональні види поширені лише в одній природній зоні та приурочені до специфічних місцезростань ${ }^{50}$. Такі види характерні для високогірних Карпат $-S$. alpina, S. herbaceae, $S$. retusa. Лише у верхній частині лісового поясу Карпат росте S. silesiaca, S. rhaetica. Слід зауважити, що S. elaeagnos i S. daphnoides поширені в Карпатах лише по берегах гірських річок і в ущелинах на висоті від 800 до $1800 \mathrm{~m}^{51}$.

У двох екотопах на території України - в Карпатах і на Поліссі представлені S. myrtilloides, S. lapponum, S. Starkeana. Лише на Поліссі й у Лісостепу поширена $S$. aurita, S. myrsinifolia. У лісостеповій і степовій зонах України представлені S. Vinogradovii, S. purpurea ${ }^{52}$.

На території Кримського півострова у природній флорі представлено лише сім видів - S. alba, S. caprea, S. cinerea, S. fragilis, S. purpurea, S. rosmarinifolia, S. triandra ${ }^{53}$.

49 Іщук Л.П. Аналіз екобіоморф автохтонних видів роду Salix L. в Україні. Aвтохтонні ma інтродуковані рослини. 2014. Вип. 10. С. 12-18.

${ }^{50}$ Іщук Л.П. Асортимент, особливості культури та перспективи використання аркто-монтанних видів роду Salix L. Науковий вісник Національного лісотехнічного університету Украӥни. 2014. Вип. 24.4. С. 28-35.

${ }^{51}$ Ishchuk L.P. Analysis of willow (Salix L.) Flora in Ukrainian Carpathians. Journal of botany. 2017. Vol. IX. №. 1 (14). P. 50-55.

${ }^{52}$ Іщук Л.П. Таксономічний склад та особливості поширення видів роду Salix L. в Українському Поліссі. Природа західного Полісся та прилеглих територій : збірник наукових праць / за ред. Ф.В. Зузука. Т. ІІ. Луцьк : Східноєвроп. нац. ун-т ім. Лесі Українки, 2017. С. 33-37.

${ }^{53}$ Ена А.В. Природная флора Крымского полуострова : монография. Симферополь : Н. Орианда, 2012. 232 c. 
Наші дослідження встановили, що до лісової зони приурочені ландшафтні групи $S$. alba, S. aurita, S. caprea, S. cinerea, S. lapponum, S. myrsinifolia, $S$. pentandra, $S$. acutifolia, $S$. silesiaca, S. rhaetica, S. triandra, S. viminalis. Серед них масово трапляються лише $S$. alba, S. caprea, S. cinerea, S. pentandra, S. triandra, S. viminalis. Решта видів трапляються спорадично поодинокими екземплярами.

У лісостеповій зоні представлені у ландшафтних групах $S$. alba, S. caprea, S. cinerea, S. fragilis, S. aurita, S. acutifolia, S. myrsinifolia, S. pentandra, S. rhaetica, S. rosmarinifolia, S. Starkeana, S. triandra, S. purpurea, S. viminalis. Масово поширені S. alba, S. caprea, S. cinerea, $S$. fragilis, S. pentandra, S. triandra, S. viminalis.

У степовій зоні широко представлені ландшафтні групи S. acutifolia, S. alba, S. caprea, S. cinerea, S. fragilis, S. pentandra, S. rosmarinifolia, $S$. triandra, S. viminalis, $S$. Vinogradovii. Масовими видами $\in$ S. cinerea, S. viminalis, S. acutifolia ${ }^{54}$.

Таким чином, у природній флорі України представлено 23 автохтонні види та ряд спонтанних гібридів. У флорі України євразійські види становлять $65,2 \%$ - 15 видів. Із них у межах субарктичного й альпійського поясу Свразії один вид - S. rhaetica Anders (4,3\%); у межах лісової зони Євразії - бореальної та неморальної - чотири види: $S$. caprea, $S$. cinerea, $S$. pentandra, $S$. viminalis $(17,4 \%)$, у межах лісової та степової зони два види $-S$. rosmarinifolia і $S$. triandra (8,6\%). До євросибірських видів належать субарктично-бореальні - S. lapponum і S. myrtilloides, два види лісової смуги - S. myrtilloides i S. Starkeana. У лісовій і степовій смузі Східної Європи та Азії трапляється S. acutifolia, у тій самій смузі Свропи та Малої Азії - S. fragilis, у гірськолісовому поясі Західної Європи та Малої Азії - S. elaeagnos.

Для Свропи характерно лише $21,8 \%$ - 5 видів (S. retusa, S. alpina ростуть у альпійському і субальпійському поясі гір Західної Європи; у лісовому поясі цих самих гір - S. silesiaca i $S$. daphnoides; у лісовій смузі Європи росте $S$. aurita). Лише два види $(8,7 \%) S$. alba, S. purpurea належать до палеоарктичних і трапляються в межах Європи, Азії та Північної Африки: перший - по всій смузі, другий - тільки у неморальній і степовій зоні. Також один голарктичний аркто-монтанний вид $S$. herbaceae $(4,3 \%)$ поширений у Свропі та Північній Америці.

Таким чином, переважна більшість роду Salix є представниками лісової смуги помірного клімату - 9 видів $(39,1 \%)$, додатково у гірськолісовому поясі трапляється два види $-8,6 \%$. Для лісової та степової смуг характерні шість видів - 26,1\%, для субарктично-бореальної смуги два

\footnotetext{
${ }^{54}$ Ищук Л.П., Голуб Н.П. Автохтонные виды рода Salix L. в степной зоне Украины. Cmenu Северной Евразии : материалы VII международного симпозиума. Оренбург : ИС УрО РАН, Печатный дом «Димур», 2015. С. 378-380.
} 
болотні види - 8,6\%. До аркто-альпійських належать три гірські види $(13,0 \%)$ і до альпійських - три види $(13,0 \%)$.

За умовами місцезростання автохтонні види роду Salix України можна розділити таким чином: на берегах рівнинних річок ростуть $S$. acutifolia, S. purpurea, S. viminalis, S. alba, S. triandra, S. fragilis, по берегах гірських річок - S. elaeagnos, $S$. daphnoides (рис. 1). Для боліт характерні S. cinerea, S. pentandra, $S$. rosmarinifolia, $S$. aurita, $S$. lapponum i S. myrtilloides. Два останні види характерні головним чином для торфових боліт. На луках ростуть $S$. cinerea, S. triandra, S. myrtilloides, S. Starkeana, S. rosmarinifolia. У лісах трапляються S. caprea, S. cinerea. У гірських лісах, крім того, росте $S$. silesiaca, на сухих материкових пісках - S. acutifolia i S. rosmarinifolia. У субальпійському поясі Карпат у екотопах ростуть $S$. herbaceae, S. retusa, S. alpina, S. rhaetica. До міських урбоекосистем найкраще адаптувалися $S$. alba, S. cinerea, S. fragilis, S. pentandra, S. caprea.

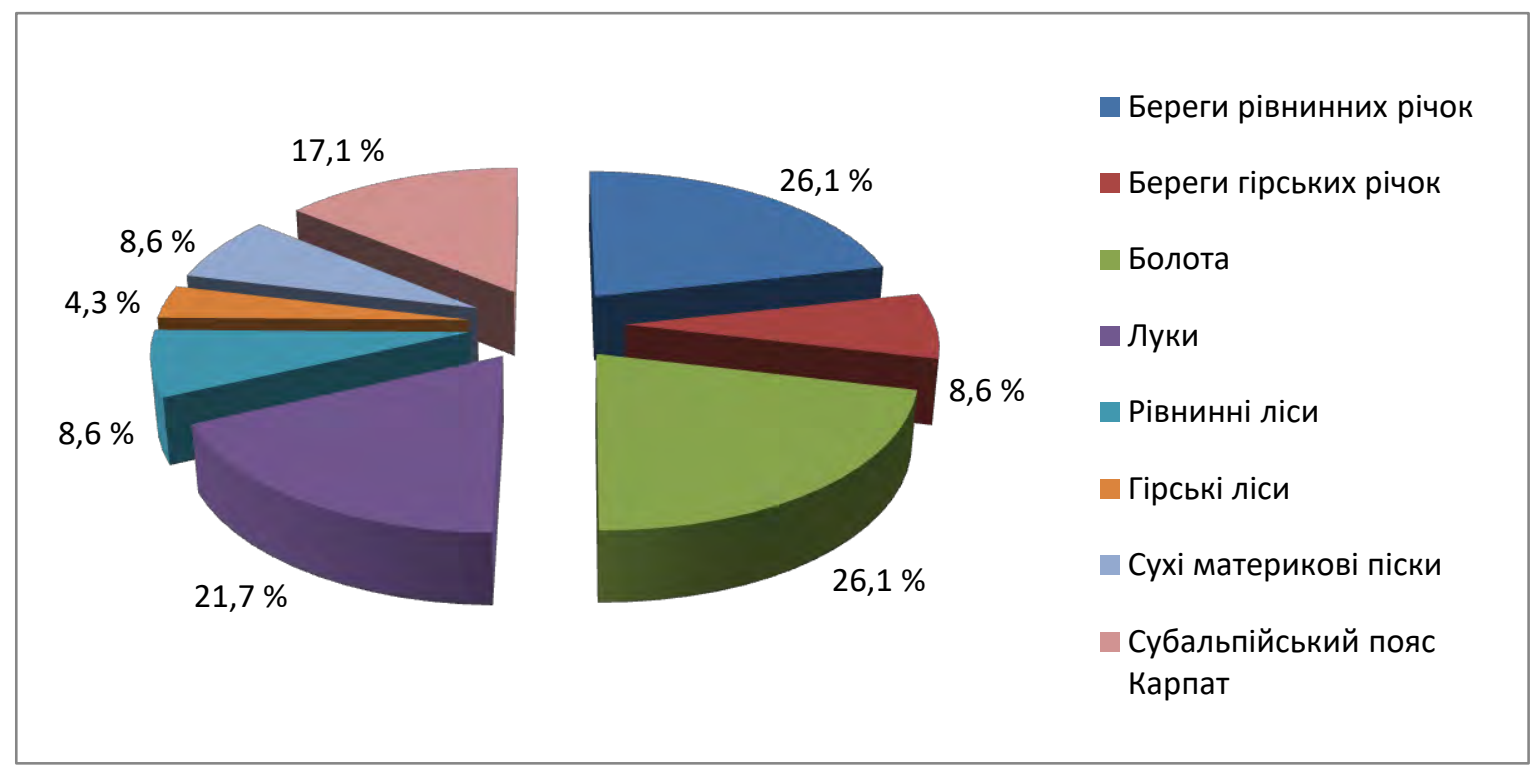

Рис. 1. Характеристика місцезростань аборигенних видів роду Salix

\section{2. Охорона рослин родини Salicaceae в Україні}

В охороні рослин родини Salicaceae на території України можна виділити декілька аспектів. Насамперед це охорона видів родини Salicaceae in situ, включаючи їхні природні оселища (біотопи) відповідно до I Бернської конвенції про охорону дикої флори та фауни ${ }^{55}$ та додатків II i IV Оселищної дерективи $\mathrm{CC}^{56}$, представлених у Національному

\footnotetext{
${ }^{55}$ Convention for the Protection of the Mediterranean Sea Against Pollution (Barcelona Convention). URL: http://europa.eu/legislation_summaries/ environment/ water_protection management/128084_en.htm. (дата звернення: 10.04.2020).

${ }^{56}$ Оселищна концепція збереження біорізноманіття: базові документи Європейського Союзу / ред. О.О. Кагало, Б.Г. Проць. Львів : ЗУКЦ, 2012. 278 с.
} 
каталозі біотопів України ${ }^{57}$. Созологічна частка фітобіоти родини Salicaceae - це раритетні види, які заслуговують на підвищену наукову увагу і яким гарантується офіційна охорона та захист завдяки занесенню їх до «червоних» списків різних рівнів (міжнародного, державного та регіонального) або аналогічних юридичних документів на правах окремої категорії раритетності ${ }^{58,59,60}$.

Нами встановлено, що сьогодні у природній флорі Україні представлено сім аркто-монтанних видів: S. herbaceae, S. retusa = S. kitaibeliana, S. myrtilloides, S. alpina $=S$. jacquinii, S. starkeana $=$ S. livida, S. rhaetica, S. lapponum ${ }^{61}$. Ще два види $S$. aurita i $S$. silesiaca зростають у середньому поясі гір і характеризуються невеликими розмірами відповідно 1,0-1,5 м і 1,0-4,0 м. Всі вони у природній флорі займають перезволожені екотопи, прирічкові заплавні долини, заболочені ділянки та високогірні альпійські луки. Особливої уваги потребують рідкісні та зникаючі види роду Salix, популяції яких невпинно скорочуються і потребують додаткових детальних досліджень.

До останнього видання Червоної книги України ${ }^{62}$ зараховано шість видів роду Salix: S. alpina, S. herbacea, S. retusa, S. lapponum, S. myrtilloides i $S$. starkeana. Всі вони охороняються на територіях і об'єктах ПЗФ вищого рангу ${ }^{63,64}$. До категорії зникаючих в Україні видів належить S. alpina, представлений єдиною ізольованою популяцією 3 невеликою площею в районі г. Близниця. Вид має вузьку екологоценотичну амплітуду, яка лімітується специфічними екологічними умовами та впливом рекреації, охороняється у Карпатському біосферному заповіднику (табл. 5).

До категорії рідкісних видів належить $S$. herbacea i $S$. retusa, ареали яких займають ізольовані популяції у гірських масивах Свидовець і Чорногора.

До категорії вразливих видів належить S. lapponum, південна межа суцільного поширення якого в Україні проходить по території

\footnotetext{
${ }^{57}$ Національний каталог біотопів України / за ред. А.А. Куземко, Я.П. Дідуха, В.А. Онищенка, Я. Шеффера. Київ : ФОП Клименко Ю.Я., 2018. 442 с.

${ }^{58}$ Bilz M., Kell S., Maxted, N., \& Lansdown, R. European Red list of vascular plants. Luxemburg : Publications Office of the European Union. 2011. 125 p.

${ }_{59}$ Офіційні переліки регіонально рідкісних рослин адміністративних територій України (довідкове видання) / укл. Т.Л. Андрієнко, М.М. Перегрим. Київ : Альтерпрес, 2012. 148 с.

${ }^{60}$ Зелена книга України / під ред. Я.П. Дідуха. Київ : Альтерпрес, 2009. 448 с.

${ }^{61}$ Іщук Л.П. Асортимент, особливості культури та перспективи використання аркто-монтанних видів роду Salix L. Науковий вісник Начіонального лісотехнічного університету Украӥни. 2014. Вип. 24.4. С. 28-35.

${ }^{62}$ Червона книга України. Рослинний світ / за ред. Я.П. Дідуха. Київ : Глобалконсалтинг, 2009. 900 с.

63 Фіторізноманіття заповідників і національних природних парків України. Ч. 1. Біосферні заповідники. Природні заповідники / кол. авт. під ред. В.А. Онищенка і Т.Л. Андрієнко. Київ : Фітосоціоцентр, 2012. 406 с.

64 Фіторізноманіття заповідників і національних природних парків України. Ч. 2. Національні природні парки / кол. авт. під ред. В.А. Онищенка і Т.Л. Андрієнко. Київ : Фітосоціоцентр, 2012. $580 \mathrm{c}$.
} 
Правобережного Полісся через Ковель - Луцьк - Рівне - НовоградВолинський - Овруч. Ізольовані місцезростання знайдені на Лівобережному Поліссі (Верхньосульський заказник на Сумщині) та в Українських Карпатах поблизу г. Говерли (урочище Цибульки). Охороняється вид у Польщі та Чехії. Зменшенню чисельності виду сприяють меліоративні роботи з осушення боліт ${ }^{65}$.

Таблиця 5

Біоекологічна характеристика видів роду Salix L., які потребують охорони в Україні

\begin{tabular}{|l|c|c|c|}
\hline \multicolumn{1}{|c|}{ Вид } & Життєва форма & $\begin{array}{c}\text { Екологічна } \\
\text { характеристика }\end{array}$ & $\begin{array}{c}\text { Природоохоронний } \\
\text { статус }\end{array}$ \\
\hline S. alpina & хамефіт & мезогігрофіт & зникаючий \\
\hline S. herbacea & хамефіт & мезофіт & рідкісний \\
\hline S. retusa & хамефіт & мезофіт & рідкісний \\
\hline S. lapponum & фанерофіт & гігрофіт & вразливий \\
\hline S. myrtilloides & фанерофіт & гігрофіт & вразливий \\
\hline S. starkeana & фанерофіт & гігромезофіт & вразливий \\
\hline
\end{tabular}

До категорії вразливих також належить S. myrtilloides, який в Україні на південній межі свого ареалу трапляється невеликими куртинами на Поліссі, Розточчі, Прикарпатті, зрідка у Лісостепу. Причина зміни чисельності - меліорація, осушення боліт і їхнє заліснення. Охороняється S. myrtilloides також у Білорусі, Латвії, Литві, Німеччині, Польщі, Румунії, Словаччині та Чехії. $€$ гербарні збори S. myrtilloides iз ПЗ Розточчя, датовані серединою 80 -х рр. минулого століття в урочищі Заливки, однак нині особини виду не знайдені, можливо, вид зник через прогресуючу сильватизацію урочища, але там трапляються окремі гібриди $S$. myrtilloides $\times S$. aurita. Також вид охороняється у заказниках загальнодержавного значення «Хиноцький» на Рівненщині та «Замглай» на Чернігівщині ${ }^{66}$.

До вразливих видів зарахований $S$. Starkeana, який в Україні поширений на південній межі ареалу і трапляється спорадично на Поліссі, у Лісостепу, Розточчі-Опіллі, Прикарпатті, Карпатах, Лівобережному та Правобережному Лісостепу. Зменшення чисельності особин відбувається на трансформованих докорінно біотопах внаслідок дії різних антропогенних факторів: випасу тварин, пожеж, будівництва.

\footnotetext{
${ }^{65}$ Іщук Л.П. До хорології та охорони видів роду Salix L. Флорологія та фітосозологія. 2014. Т. 3-4. C. $38-42$.

${ }^{66}$ Іщук Л.П. Асортимент, особливості культури та перспективи використання аркто-монтанних видів роду Salix L. Науковий вісник Національного лісотехнічного університету Украӥни. 2014. Вип. 24.4. С. 28-35.
} 
Також охороняється вид у заказнику «Верхобузьке болото» на Львівщині.

На лівому березі заплавної тераси обабіч автошляху «Світлогірське Кобеляки» в районі залізного мосту через р. Ворсклу нами також виявлено острівне місцезростання S. Starkeana ${ }^{67}$. На пагонах куща видно наслідки минулорічної пожежі, але він добре відновився і перебував у задовільному стані. Слід зауважити, що це - найпівденніше місцезростання виду в Україні - знаходиться за сотню кілометрів від межі його суцільного ареалу, яка проходить по лінії Харків - Полтава Лубни - Канів - Вінниця - Рогатин - Львів - Мостиськ. S. Starkeana також охороняється у Німеччині, Румунії, Словаччині, Чехії та Росії ${ }^{68}$.

Не менш важливим і гострим є питання охорони біотопів (оселищ) 3 участю рослин родини Salicaceae. Такі угруповання виконують созологічну функцію, оскільки під наметом цих видів знаходяться біотопи трав'яних рослин, занесених до Червоної книги України, Європейського Червоного списку і Червоної книги МСОП ${ }^{69,} 70$. Найбільш повний опис біотопів наближений до європейського, але адаптований до наших природних умов і за участі автохтонних видів родини Salicaceae представлений у Національному каталозі біотопів України ${ }^{71}$, де виділено 18 біотопів з участю видів родини Salicaceae.

Другим аспектом є охорона видів роду Salix ex situ на територіях та об'єктах природно-заповідного фонду України, зокрема у ботанічних садах і дендропарках ${ }^{72}$.

Третім аспектом охорони є охорона вікових і монументальних дерев родини Salicaceae. Особливе місце серед насаджень займають вікові дерева, які зазвичай збереглися у ландшафтних парках XVIII-XIX ст. та в історичних частинах міст i селищ. Шляхом аналізу реєстрів i охоронних списків унікальних і меморіальних дерев нами встановлено, що до цього списку внесено лише 14 дерев автохтонних видів $P$. alba, $P$. tremula, P. nigra, причому з них охоронний статус мають лише чотири дерева $^{73}$. Очевидно, це пов'язано 3 тим, що автохтонні види найкраще адаптовані до місцевих грунтово-кліматичних умов. На території

\footnotetext{
${ }^{67}$ Іщук Л.П., Смоляр Н.О. Сучасний стан, продуктивність і созологічна цінність корінних вербовотополевих угруповань у пониззі річки Ворскли. Наукові записки Тернопільського педагогічного університету. Серія : Біологія. 2017. № 1 (68). С. 52-58.

${ }^{68}$ Червона книга України. Рослинний світ / за ред. Я.П. Дідуха. Київ : Глобалконсалтинг, 2009. 900 с.

${ }^{69}$ Interpretation manual of European Union Habitats. European Commission DG Environment Nature and Biodiversity. Nature ENV B.3. 2013. URL: http://ec.europa.eu/environment/ nature/legislation/habitatsdirective/ docs/Int_Manual_EU28.pdf (дата звернення: 10.04.2020).

${ }^{70}$ Червона книга України. Рослинний світ / за ред. Я.П. Дідуха. Київ : Глобалконсалтинг, 2009. 900 с.

71 Національний каталог біотопів України; за ред. А.А. Куземко, Я.П. Дідуха, В.А. Онищенка, Я. Шеффера. Київ : ФОП Клименко Ю.Я., 2018. 442 с.

${ }^{72}$ Каталог раритетних рослин ботанічних садів і дендропарків України : довідниковий посібник / за ред. А.П. Лебеди. Київ : Академперіодика, 2011. 184 с.

${ }_{73}$ Стародавні дерева України: реєстр-довідник / П.І. Гриник, М.П. Стеценко, С.Л. Шнайдер та ін. Київ : ПРООН Україна, 2010. 143 с.
} 
дендрологічного парку «Олександрія» НАН України нами виявлено чотири дерева Populus, які підлягають охороні ${ }^{74}$ (табл. 6).

Таблиця 6

Характеристика вікових видів роду Рориlus дендрологічного парку «Олександрія» НАН України

\begin{tabular}{|c|c|c|c|c|c|c|}
\hline $\begin{array}{l}\text { № } \\
\text { 3/ח }\end{array}$ & Вид & $\begin{array}{c}\text { Місцезнахо- } \\
\text { дження, } \\
\text { квартал }\end{array}$ & $\begin{array}{l}\text { Вік, } \\
\text { років }\end{array}$ & $\begin{array}{c}\text { Висота, } \\
\text { м }\end{array}$ & $\begin{array}{c}\text { Обхват } \\
\text { стовбура, } \\
\text { м }\end{array}$ & $\begin{array}{l}\text { Ширина } \\
\text { крони, м }\end{array}$ \\
\hline 1 & P. nigra & 29 & $>150$ & 33 & 7,1 & 25 \\
\hline 2 & P. $\times$ canescens & 29 & $\approx 120$ & 30 & 6,3 & 15 \\
\hline 3 & P. $\times$ canescens & 29 & $\approx 120$ & 22 & 4,5 & 14 \\
\hline 4 & P. $\times$ canescens & 30 & 100 & 28 & 5,7 & 16 \\
\hline
\end{tabular}

Це унікальні 100-150-річні дерева, які ростуть у заплаві р. Рось, перебувають у задовільному стані і мають сухі гілки у середній частині крони. Одне $з$ дерев $P$. × canescens уражене двома кущами напівпаразита Viscum album L. Проте багато вікових дерев видів роду Populus не вдається зберегти. І потерпають вони зазвичай не від природної старості, а від надмірного антропогенного навантаження.

Четвертий аспект охорони - це охорона «чистих» видів, оскільки види родини Salicaceae дуже поліморфні та легко схрещуються між собою, утворюючи численні природні гібриди. Постає ця проблема у деяких країнах Свропи ${ }^{75}$, однак в Україні поки що не актуальна.

\section{ВИСНОВКИ}

Проведені дослідження дозволили уточнити сучасний таксономічний склад родини Salicaceae в Україні in situ. Встановлено, що рід Populus представлено лише трьома видами: $P$. alba, $P$. tremula, $P$. nigra й одним природним гібридом $P$. $\times$ canescens (Ait.) Smith. Рід Salix на території України представлений 23 автохтонними видами. Два види S. hastata і S. reticulata, імовірно, відсутні в Україні, оскільки не підтверджені сучасними гербарними зразками. До секції Salix належать 4 види: $S$. triandra L., S. pentandra, S. alba L., S. fragilis L. До секції Chamaetia4 види: S. myrtilloides L., S. herbaceae L., S. retusa, S. alpina Scop. До секції Vetrix - 15 видів: S. myrsinifolia Salisb., S. caprea L., S. cinerea L., S. aurita L., S. Starkeana Willd., S. lapponum L., S. silesiaca Willd.,

74 Іщук Л.П. До проблеми збереження вікових тополь. Науковий вісник Національного університету біоресурсів і природокористування Украӥни. Серія : Лісівництво та декоративне садівниитво. 2015. Вип. 229. С. 250-259.

${ }^{75}$ IUCN. The IUCN Red list of Threatened Plants, compiled by the World Conservation Monitoring Centre, 1715 p. IUCN Red List of Threatened Species version 2019-1. URL: https://www.iucnredlist.org (дата звернення: 15.05.2020). 
S. viminalis L., S. acutifolia Willd., S. daphnoides Vill., S. rosmarinifolia L., S. elaeagnos Scop., S. rhaetica Anders., S. purpurea L., S. Vinogradovii Skvorts.

На основі аналізу проведено розподіл ареалів видів роду Salix, поширених в Україні за географічним принципом. Кількісний розподіл за ареалами видів роду Salix показує, що приблизно рівне число видів має багатозональний ареал (Свразія), європейський і євро-сибірський.

Десять видів (S. fragilis, S. myrtilloides, S. lapponum, S. caprea, S. aurita, S. starkeana, S. purpurea, S. vinogradovii, S. viminalis, S. myrsinifolia) перебувають в Україні на південній або південно-східній межі своїх ареалів, що пояснюється зміною клімату 3 північного заходу на південний схід країни. Сім видів (S. herbacea, S. retusa, S. alpina, S. silesiaca, S. rhaetica, S. daphnoides $i$ S. elaeagnos) мають острівне поширення тільки в Українських Карпатах і потребують охорони. Аналіз місцезростань автохтонних видів роду Salix показав, що найбільша кількість видів займають береги рівнинних річок, болота і луки.

Незважаючи на різноманіття рослин родини Salicaceae, ряд видів потребує охорони. До останнього видання Червоної книги України (2009) зараховано 6 видів роду Salix, iз яких S. alpina належить до категорії зникаючих, S. lapponum, S. myrtilloides, S. starkeana - до вразливих, а $S$. herbacea, $S$. retusa - до категорії рідкісних. Всі ці види охороняються на територіях і об'єктах ПЗФ вищого рангу. Основними причинами зменшення чисельності аркто-монтанних видів роду Salix є порушення гідрологічного режиму, осушення боліт, розробка торф'яників, випасання тварин, витоптування і знищення рослин внаслідок рекреації. Біотопи за участю видів родів Populus i Salix в Україні також мають созологічну цінність, приурочені до боліт, заплав рівнинних річок або високогір'я Карпат і потребують природоохоронного менеджменту.

Враховуючи біологічні особливості, які зумовлюють порівняно невисоку тривалість життя рослин родини Salicaceae, в Україні існує проблема збереження цих вікових дерев. Причиною незадовільного виявлення та реєстрації вікових і монументальних дерев родини Salicaceae $є$ відсутність системного підходу до цього питання на державному рівні. Прикладом збереження вікових тополь може стати дендропарк «Олександрія», де зростають 4 особини віком понад 100 років.

\section{АНОТАЦІЯ}

Глобальні зміни клімату і надмірне антропогенне навантаження на річкові та прирічкові екосистеми створюють проблеми збереження, збагачення і відновлення видового та внутрішньовидового різноманіття рослин родини Salicaceae. Тому напрацювання і впровадження питань 
таксономічного складу, хорології, екології й охорони рослин родини Salicacaea актуальні для ботаніки, дендрології, фітоценології, фітомеліорації, селекції та збагачення фіторізноманіття природних екосистем. На основі експедиційних досліджень та аналізу гербарних зразків у провідних гербаріях України (KW, LW, LWS, UU, PWU, TERN*, CWU, YALT) встановлено хорологію і таксономічний склад автохтонних видів родини Salicaceae, який налічує 27 таксонів три види й один природний гібрид роду Populus і 23 види роду Salix. Місцезростання двох видів $S$. reticulata i S. hastata потребують уточнення.

Проаналізовано видові таксони роду Salix i їхню хорологію у ботаніко-географічних зонах України, на основі класифікації за географічним принципом виділено вузько- і широкозональні види, масові та поодинокі види, визначено ландшафтні групи для Полісся, Лісостепу, Степу, Криму і Карпат і проаналізовано місцезростання видів.

Охорона рослин родини Salicaceae в Україні відбувається in situ та ex situ, включаючи їх природні оселища. Шість видів - S. alpina, $S$. herbacea, S. retusa, S. lapponum, S. myrtilloides i S. starkeana - занесено до Червоної книги України. На державному рівні потребують хорони вікові та монументальні дерева родини Salicaceae.

\section{ЛІТЕРАТУРА}

1. Андриенко Т.Л. Мелкие болотные ивы (Salix lapponum, S. myrtilloides, S. rosmarinifolia). Ботанический журнал. 1980. Т. 65. № 6. С. 843-848.

2. Брадіс C.M. Salix L. Визначник рослин Украӥни / за ред. Д.К. Зерова. Київ : Урожай, 1965. С. 186-193.

3. Голяка Д.М., Білоус А.М., Голяка М.А. Фітомаси чагарникових верб у природних фітоценозах Чернігівського Полісся : монографія. Київ : НУБіП України, 2018. 227 с.

4. Горєлов О.М. Родина Salicaceae Mirb. Дендрофлора України: Дикорослі й культивовані дерева і кущі. Покритонасінні / за ред. М.А. Кохна. Київ : Фітосоціоцентр, 2002. Ч 1. С. 336-379.

5. Ена А.В. Природная флора Крымского полуострова : монография. Симферополь : Н. Орианда, 2012. 232 с.

6. Зелена книга України / під ред. Я.П. Дідуха. Київ : Альтерпрес, 2009. $448 \mathrm{c}$.

7. Іщук Л.П. Аналіз екобіоморф автохтонних видів роду Salix L. в Україні. Автохтонні та інтродуковані рослини. 2014. Вип. 10. С. 12-18.

8. Іщук Л.П. Асортимент, особливості культури та перспективи використання аркто-монтанних видів роду Salix L. Науковий вісник 
Національного лісотехнічного університету України. 2014. Вип. 24.4. C. 28-35.

9. Іщук Л.П. До проблеми збереження вікових тополь. Науковий вісник Національного університету біоресурсів і природокористування Украӥни. Серія : Лісівництво та декоративне садівництво. 2015. Вип. 229. С. 250-259.

10. Іщук Л.П. До хорології та охорони видів роду Salix L. Флорологія та фітосозологія. 2014. Т. 3-4. С. 38-42.

11. Іщук Л.П. Рід Salix L. в Україні. Bicmi біосферного заповідника «Асканія-Нова». 2015. Вип. 17. С. 97-100.

12. Іщук Л.П. Родина Salicaceae Mirbel.: біологія, адаптаційний потенціал, охорона та використання в Україні : дис. ... докт. біол. наук : 03.00.05. Київ, 2019. 585 с.

13. Іщук Л.П. Таксономічний склад та деякі аспекти використання автохтонних видів роду Salix L. в Українських Карпатах. Основні проблеми ци тендениії подальшого розвитку лісового господарства в Українських Kapnaтах : зб. матеріалів Міжнародної науково-практичної конференції (4-5 жовтня 2018 р., м. Івано-Франківськ). Івано-Франківськ : HAIP, 2018. C. 210-215.

14. Іщук Л.П. Таксономічний склад та особливості поширення видів роду Salix L. в Українському Поліссі. Природа західного Полісся та прилеглих територій : збірник наукових праць / за ред. Ф.В. Зузука. Т. ІІ. Луцьк: Східноєвроп. нац. ун-т ім. Лесі Українки, 2017. С. 33-37.

15. Іщук Л.П., Смоляр Н.О. Сучасний стан, продуктивність і созологічна цінність корінних вербово-тополевих угруповань у пониззі річки Ворскли. Наукові записки Тернопільського педагогічного університету. Сер. Біологія. 2017. № 1 (68). С. 52-58.

16. Ищук Л.П., Голуб Н.П. Автохтонные виды рода Salix L. в степной зоне Украины. Степи Северной Евразии : материалы VII международного симпозиума. Оренбург : ИС УрО РАН, Печатный дом «Димур», 2015. С. 378-380.

17. Каталог раритетних рослин ботанічних садів i дендропарків України : довідниковий посібник / за ред. А.П. Лебеди. Київ : Академперіодика, 2011. 184 с.

18. Крічфалушій В.В. Види роду Salix L. в Українських Карпатах. Украйнський ботанічний журнал. 1982. 39, № 2. С. 52-56.

19. Малиновський К. Рослинність високогір'я Українських Карпат. Київ : Наук. думка, 1980. 276 с.

20. Морозов И.Р. Определитель ив и их культура. Москва : Лесная промышленность, 1966. $254 \mathrm{c.}$

21. Назаров M.І., Котов M.I., Гержедович П.I. Вербові (Salicaceae Lindl.). Флора УРСР. Київ : Вид-во АН УРСР, 1952. Т. IV. С. 17-86. 
22. Національний каталог біотопів України / за ред. А.А. Куземко, Я.П. Дідуха, В.А. Онищенка, Я. Шеффера. Київ : ФОП Клименко Ю.Я., 2018. $442 \mathrm{c}$.

23. Оселищна концепція збереження біорізноманіття: базові документи Свропейського Союзу / ред. О.О. Кагало, Б.Г. Проць. Львів : ЗУКЦ, 2012. 278 с.

24. Офіційні переліки регіонально рідкісних рослин адміністративних територій України (довідкове видання) / укл. Т.Л. Андрієнко, М.М. Перегрим. Київ : Альтерпрес, 2012. 148 с.

25. Скворцов А.К. Ивы СССР. Москва : Наука, 1968. 262 с.

26. Скворцов А.К. Salix L. Определитель высших растений Украины. Київ : Наук. думка, 1987. С. 130-133.

27. Старова Н.В. Селекция ивовых. Москва : Лесн. пром-сть, 1980. $208 \mathrm{c}$.

28. Стародавні дерева України : реєстр-довідник / П.І. Гриник, М.П. Стеценко, С.Л. Шнайдер та ін. Київ : ПРООН Україна, 2010. 143 с.

29. Фіторізноманіття заповідників і національних природних парків України. Ч.1. Біосферні заповідники. Природні заповідники / кол. авт. під ред. В.А. Онищенка і Т.Л. Андрієнко. Київ : Фітосоціоцентр, 2012. $406 \mathrm{c}$.

30. Фіторізноманіття заповідників і національних природних парків України. Ч. 2. Національні природні парки / кол. авт. під ред. В.А. Онищенка і Т.Л. Андрієнко. Київ : Фітосоціоцентр, 2012. 580 с.

31. Червона книга України. Рослинний світ. Київ : Українська енциклопедія, 1996. 486 с.

32. Червона книга України. Рослинний світ / за ред. Я.П. Дідуха. Київ : Глобалконсалтинг, 2009. 900 с.

33. Чопик В., Федорончук М. Флора Українських Карпат. Тернопіль : ТзОВ «Терно-граф», 2015. $712 \mathrm{c}$.

34. Bilz M., Kell S., Maxted, N., Lansdown, R. European Red list of vascular plants. Luxemburg : Publications Office of the European Union. 2011. $125 \mathrm{p}$.

35. Convention for the Protection of the Mediterranean Sea Against Pollution (Barcelona Convention). URL: http://europa.eu/legislation summaries/environment/water_protection_management/ 128084_en.htm (дата звернення: 10.04.2020).

36. Domin K. Additarnenta ad cognitionem florae Rossiae Subcarpaticae. Acta bot. Bohem. Praha, 1929. № 8 (37). P. 35-44.

37. Interpretation manual of European Union Habitats. European Commission DG Environment Nature and Biodiversity. Nature ENV B.3. 2013. URL: http://ec.europa.eu/environment/nature/legislation/habitatsdirective/docs/ Int_Manual_EU28.pdf (дата звернення: 10.04.2020). 
38. Ishchuk L.P. Analysis of willow (Salix L.) Flora in Ukrainian Carpathians. Journal of botany. 2017. Vol. IX. № 1 (14). P. 50-55.

39. IUCN. The IUCN Red list of Threatened Plants, compiled by the World Conservation Monitoring Centre, 1715 p. IUCN Red List of Threatened Species version 2019-1. URL: https://www.iucnredlist.org_(дата звернення: 15.05.2020).

40. Skvortsov A.K. Willows of Russia and Adjacent Countries. Taxonomical and Geographical Revision. Joensuu : University of Joensuu, 1999. $307 \mathrm{pp}$.

41. The Angiosperm Phylogeny Group. An update of the Angiosperm Phylogeny Group classification for the orders and families of flowering plants: APG IV. Botanical Journal of the Linnean Society. 2016. Vol. 181. № 1 (24 March). P. 1-20. DOI:10.1111/boj.12385.

42. Woloszczak E. Kritische Bemerkungen uber sieben burgische Weiden. Osterreich. bot. Z. 1889. № 39. P. 291-295, 330-332.

43. Zapałowicz H. Conspectus florae Galiciae criticus. Krytyczny Przegląd Roślinności Galicji. Kraków : Akademia Umiejętności, 1908. Vol. 2. 368 p.

44. Zapałowicz H. Roślinna szata gớr Pokucko-Marmaroskich. Sprav. Kom. Fizjogr. Umiej, 1889. 389 p.

45. Szafer W. Salicaceae. In: Flora Polska. 1921. № 2. S. 24-47. Krakow.

Information about authors: Ishchuk L. P. Doctor of Biological Sciences, Associate Professor at the Department of Landscape Architecture and Planning

Bila Tserkva National Agrarian University 8/1, Soborna area, Bila Tserkva, Kiev region, 09111, Ukraine Ishchuk H. P., Candidate of Agricultural Sciences, Associate Professor at the Department of Forestry Uman National University of Horticulture 1, Institutska str., Uman, Cherkassy region, 20305, Ukraine 